\title{
TERRORISM AND ITS IMPLICATION TOWARDS THE RELIGIOUS EDUCATION
}

\author{
CHOIRUL FUAD YUSUF
}

Diskusi tentang terorisme sangat aktual dan penting, paling tidak bagi beberapa negara yang sedang dituduh sebagai pusat latihan dan kegiatan para kader teroris-baik skala lokal maupun internasional. Tulisan ini mencoba mengelaborasi dan menjelaskan bagaimana terorisme berpengaruh terhadap hampir seluruh aspek kehidupan masyarakat baik politik, ekonomi, budaya, dan agama. Lebih lanjut, tulisan ini mencoba untuk menjelaskan bagaimana seharusnya pendidikan agama sebagai bagian dari sistem pendidikan nasional memberikan berbagai respon dalam kaitannya dengan kebutuhan masyarakat dalam mengkounter terorisme di negaranya

\section{Terrorism as the Global}

\section{Phenomena}

The issue of terrorism is not something new. Historically, this term had been very popular since some decades later. As a global phenomenon, the word "terrorism" which was derived from the Greece word "terrere" or Latin word "terreo" (: means to frighten, to make a person or people fear) ${ }^{1}$ can be traced its root in the English language to French Revolution (1789-1795) when The British stateman Edmund Burke used the term to describe the action of Jacobindominated French Government. During a period of the French Revolution known as the Reign of Terror (1793-1794) under the leadership of Maximilien Robes-

${ }^{1}$ K. Prent c.m, J.Adisubrata, and 'W.J.S Poerwadarminta, Kamus Latin-Indonesia, Kanisius, Semarang, 1969, p.859. 
pierre, thousands of "enemies of the state" were put on trial and guillotined. It was estimated that 500.000 citizen were arrested, 40.000 were executed, and 200.000 were deported and another 200.000 died in prison from starvation and torture. ${ }^{2}$ In this case, terrorism to be referred to all activities causing the terror, including any activities done by the state. In its development, because of terrorism is always changing, so terrorism, then was defined and understood through many perspectives and ideological interests. Walter Laqueur, in The Age of Terrorism (1987) stated that "No definitions of terrorism can possibly cover all the varieties of terrorism that have appeared throughout history". But, most defintions tend to be more dominantly formulated by the states interest. ${ }^{3}$ A.P. Schmid, a terrorism expert, for instance, defines widely terrorism as " an anxiety-inspiring method of repeated violent action, employed by (semi-)clandestine individual group or state actors, for idiosyncratic, criminal, or political reasons, whereby the direct targets of violence are not the main targets" ${ }^{34}$ While The official of the United State Government defines terrorism as "premeditated, politically motivated violence perpetuated against noncombantant targets by subnational groups or clandestine agents usually intended to influence an audience." Then, FBI defines the terrotism as "the violent actions, acted by nonstate actors wanting to make society feel "being terror or fear". Terrorism, according to FBI, is usually intended to intimidate or coerce a government, the civilian population, or any segment thereof, in furtherance of political or social objectives by using the unlawful force or violence.

Definitions of terrorism above, substantially, are not further different from the Islamic Conference Organization $(O K J)$ which formulates terrorism as "any act or threat of violence, notwithstanding its mo-

2 "The Criminology of Terrorism : History, Law, Definitions and Typologies", dalam Course Readings : Foundation for Senior Officer, The Distillary, Jeff Penrose (Project Director), p.78.

${ }^{3}$ The use of the term of terrorism by the states, philosophically, tends to be more understandable because the owner of political legitimation and sovereignty is politically the legitimate state. Dealing with this political argument, Weber underlined that the holder of the state's sovereignty is contractually acceptable by the citizens as the legitimate user of the coercions or violent authority for the summum bonum (public benefits).

${ }^{4}$ See: http://www.odccp.org/odccp/terrorism-definitions.html 
tives, perpetrated to carry out a criminal plan to terrorise people, threaten to harm them or endanger their lives. ${ }^{5}$ Analysing those definitions, it will be easily drawn any conclusion that definitions of terrorism tend to be formulated by the government or the state as the legitimation holder and also as the counter of the terrorist acts in at once.

Whatever definition formulated and whoever defines it, terrorism as any violent acts, historically, has various motivational background. In this case, at least, some terrorism motivated by political interest such as "the protest to Government's policies", "dissatisfaction toward certain leaders", "upholding the syariah Islamiyah", and also motivated by cultural motives as "stopping the Islamic cultural destruction by the West, and building the fundamentalist regime in the Muslim World", 6 or "to counter any cultural values, norms or tradition perceived destructive, ${ }^{7}$ and motivated by religious factors, such as : "sense to be marginalized by other religious group", "feeling to be treatened unproportionally", "protest to the Government to fulfil their religious wants or aspirations", etc. As examples, any global organizations characterized as "the terrorist group" are Al Qaeda and Hammas. Al Qaida as a clandestine has solid and strong international network in the world, such as in Africa, Asia, and other continents. $^{8}$

Through the Al Qaeda's publication, Al Neda website-which is published in Arabic-Al Qaeda disseminates its anti-American and Anti-Western messages-which persuade the world to hate or-at least— to compete against Islam as the political power in the world. Al Qaeda messages, in this case, usually emphasizes to publish three basic themes, viz : (1) the West is

${ }^{5}$ The International Convention for the Suppression of the Financing of Terrorism, December, 1999, 2178 UNTS 38349.

${ }^{6}$ Avyanthi Aziz, "Evolusi terorisme : Meninjau Teror dan Kekerasan dalam Konteks Historis", in the Jurnal InteNjien dan Kontra-Intelijen, Vol.1 no.6, Jakarta, Centre for the Study of Intelligence and Counter Intelligence, p. 31.

${ }^{7}$ In this case, some global phenomena causing the religious destruction, such as the growth of secularism, etc. (See: "Religiosity a Last-Gasp Attack On Increasingly Secular World", by Bruce Mazlish, Jakarta Post, November, 30, 2006.

${ }^{8}$ The Countries claimed as the lands for the global jihad of Al Qaeda are Afghanistan, Sudan, Somalia, Eritrea, Bosnia, Chechnya, Kashmir, Philippines, Maluku, Poso. While Al 
implacably hostile to Islam, (2) the only way to address this threat and the only language that the West understands is the logic of violence, and (3) Jibad is the only optionexecuted in certain targetted countries?

As a result, currently, American foreign policy faces a critical threat from the Muslim World in the form of a deeply embedded and rapidly growing anti-American in the Muslim World. ${ }^{10}$ The recent collective demos of the Muslims in some cities rejecting the visit of President George W. Bush to Indonesia, is an example of the negative perception and the hatred towards the American policy or the West.

Having seen the above networks, Indonesia as the muslim country was hypothetically lebelled as one of the terrorist activities centers by the global society who culturally lacks of any comprehensive information of the muslim world. At least, for the past five years, in which a mental picture has been formed in the minds of many Westerners : an image of the world of Islam as the breeding ground of terrorist and an abode of religious fundamentalism...."

\section{Terrorism in Indonesia}

The failure of The New Order Regime under the President Suharto resulted in a great deal of significant changes in nearly all aspects of life of the Indonesian people. At the macroscopic level, for instance, the changes occurred, in facts, placed the Indonesian people in the transitional position, begin-

Qaeda's doctrine of Jihad, amongst them are : estabishing the Allah's victory on earth by means of upholding the syariat Islam, defending Islam against the global conspiracy (apostate government) who willingly to destroy Islam in the world, struggling for muslim liberation, and also wanting to build the Khilafat al Islamiy (Islamic global or universal state). Source: Theory of Counter Terrorism Recognition \& Multilateral Collaboration for Combating Terrorism, The Distilary in cooperation with Faculty of Law, Wollongong University and Center for Counter Terrorrism Study and Research, Singapore.

${ }^{9}$ Paul Eedle, the British Journalist, "The Language of Jihad", presented at the Third Annual Conference of the Center for the Study of Terrorism and Political Violence, St. Andrew University, Scotland, 8 June 2002.

${ }^{10}$ Most the Muslim World perceive that the contemporary realities of the West as'imperial, morally decadent, secular, and the Western power and values as the cause of all muslim problems. See : M.A. Muqtedar Khan, "Radical Islam and'Liberal Islam" in Current History, Vol102, No.668, Dec.2003, p.417-421. 29. 2006 .

"Hassan Wirajuda, "Challenging stereotyping of /slam, West", The Jakarta Post, November 
ning from the socio-political changes into the changes of the other sectors.

At the socio-political aspects, in this case, the fall of the New Order Regime in 1998, politically, brought about the significant changes to rearrange the life quality of Indonesian people which have been experiencing difficult times in almost all aspects of life-economic, political, and cultural aspect. Such condition was primarily caused by the fundamental economic weakness besides vatious social factors related to the weakness of social ties and law upholding actions in society, which, in turn, increased the political temperature and also evoked sociopolitical flamings with all its implications. The social movements emerged with their various modus operandi such as social-protests and the likes, in this case, actually showed their social-dissatisfaction, disappointment and other social ecomomic deprivations which were historically structured since the New Order Regime in the past.

The transitional dynamic occurred-giving any chances widely for freedom, opennes, democracy, and any other refor-mative ideas and actions-in fact, affected significantly the growth of Islamic movements in Indonesia-in which during the period of the New Order Regime could not ex-press their political aspirations and ideals openly. In this transitional period, there seems to be a wide opportunity for any groups to exist and express their wants and ideals, as well as for religious movements to revive and struggle their aspira-tions and needs.

Consequently, during the post era of the New Order, a large number of Islamic movements have been arisen, for examples: Forum Komunikasi Ablussunnab Wal Jamaah/ FKAWJ (Ablussunnab Wal Jamaah Communication Forum), which is more popular with Laskar Jibad, Hizbut Tabrir, Majlis Mujabidin Indonesia/MMI (Indonesian Mujahidin Council), Front Pembela Islam/FPI (Islamic Defender Front), Front Pemuda Islam Surakarta/FPIS (Surakarta Islamic Youth Front), Forum Ulama Umat Indonesia (Indonesian Forum for Ulama), Komite Persiapan Penegakan Syariat Islam (Committee for the Implementation of Syariat Islam), Komite Indonesia untuk Solidaritas Dunia Islam/KISDI (Indonesian Committee for Islamic World Solidarity), and also Jaringan Islam Liberal/JIL (Liberal Islamic Network), and many other Islamic movements whether in the form of "religiously, politically, or culturally based" 
movements. Amongst those Islamic movements, actually, does not appear in a sudden and unpredictable moment. But it embrionally tends to appear into surface at the time before the era of Government under president Jusuf Habibie, Abdurrahman Wahid, and Megawati.

The emergence of Islamic movements in Indonesia, in the one hand, has a great influence to change the social life, particularly in controlling any religious behavior deviation in the field of pornography, prostitution, alcoholic drink (miras), and the like. Furthermore, some movements are also be able to influence the governments' policies in handling various crucial problems in Indonesia, dealing with the muslim's aspiration.

However, some Islamic movements emerged in our country, are considered as a political and economic obstacles causing the new problematic agenda. In this respect, some of the movements, are generally issued as the terrorist movements, because of their operations that bring about the condition of being terror. The impact of this condition emerged, is ofcourse, inflicted a loss upon the people in various life dimension.
Psychologically, the people feels "being terrorized", insecure, and scaredful. Politically, in a more wide perspective, besides any movements causing of being unstable society, they also lebelled the Indonesia as the source of the terrorists movements. The speedy growth of the Islamic movements with their variant both in the local, national, and global scale in Indonesia with their various actions, on the one hand, and the needs for the condusive and integrative situation which are characterized by the harmonious relations amongst people, the minimum occurences of the social conflicts, and the low of social tension in the society at large on the other hand, so the efforts for reconstructing such conditions is very necessary to develop.

\section{Terrorism and Its'Implication towards the Objective of Education}

An education plays a very important role in improving the quality of society in almost every aspect of life-economic, political, cultural, etc. Education increases a quality level of economic welfare. Education develops the people's awareness to become good citizens. 
Furthermore, education also cultivates any values and norms which are socially acceptable in a society.

How important, determinative and strategic the role of education in changing human culture and civilization, so the process of education, teleologically, has to be oriented in building the national culture and civilization. National education must be engineered and designed as effective and efficient as possible on behalf of building a strong, integrated, unified and religious nation. In short, an education has to be planned and controlled systemicly in a purpose of fulfilling the society needs today and in the future.

In the process of education, an objective of education plays an important role in obtaining the effectiveness of learning-teaching pro- cess. The level of clarity of an objective will systemicly influence the process'of education itself. In short, the objective encolours the process, and also determines the final product of education itself. In regard of the terrorism phenomena and other violent actions appeared in our country, the education process must be an effective tool for socializing and disseminating any political, doctrinary, and cultural values which are functionally useful for strengthening nation or integrating plurality, multiculturality, and multi-religiosity of the people. In this purpose, an education has to be oriented to building and strengthening of (1) nationalism ${ }^{12}$, universalism, respecting to the Human Rights, and (2) pluralism and multiculturalism ${ }^{13}$. Specifically, any process of education must be capable of transform-

\footnotetext{
${ }^{12}$ Nationalism, in this regard, is any belief in or feeling of belonging to a people united by common historical, lingistic, and perhaps racial or religious ties, where this people is identified with a particular territory and' either constitutes a nation state or has' operations to do so. (See : David Jary and Julia Jary, Unwin Hyman Dictionary of Sociology, HarperCollins Publishers, Leiicester, 1991, p.435. Among of some basic ideas of nationalism are : (1) humanity is naturally divided into nations, (2) each nation has its peculiar character, (3) the source of all political power is the nation, the whole collectivity, (4) for freedom and selfrealization, men must identify with a nation, (5) nations can only be fulfilled in their own state, (6) loyalty to the nation-state overrides other loyalties, and (7) the primary condition of global freedom and harmony is the strengthening the nation-state (See: Anthony Smith, Theories of Nationalism, $2^{\text {nd }}$ Edt., Duckworth, London, 1983, p.21.

${ }^{13}$ Multiculturalism, philosophically, refers to the belief that in the real reality of life, there is a diversity or plurality of nationality, race, ethnicity, language, tradition, religion, interest and the like which has to respected, accpeted, and operated. Many social scientists termed it as "cultural pluralism". Based on this definiton, it is assumed that multiculturalism
} 
ing and developing the religious inclusivism ${ }^{14}$. Teaching and learning of any doctrine of a certain religion should be able to create the condusive atmosphere which mobilizes the growth of awareness to be unified and integrated in the same frame of nation. On the contrary, religious exclusivism have to be eliminetd or at least to be reduced. By this orientation, Indonesian people - which is culturally, religiously, and ethnically plural—will become stronger, more integrated, and of course will be faster in reaching the final goal of the nation. From this analysis, it has been clear that, the awareness of plurality, of multiculturality, multireligiosity, and of being togetherness, is something necessary to realize "the progress" now and in the future. In other word, it will be very impossible to realize the progress, without those conditions.

\section{Implication towards the Religious Curriculla}

United Nation Report on The Global Peace stated that the global peace and security, beside economic and environmental needs are the prior agenda, at least for some decades forward. Those security demands, beside systemicly arisen from the growth of terrorism phenomena and caused by the global appearances occurred in the worldwide, such as : proverty, insecurity, and global conflicts whether politically and culturally involving many parties or interest groups, it is also predominantly caused by some religiously-based conflicts-according to the operational definition of terrorism formulated by UNO and other western countries-characterized as the terrorism's activities.

The curriculum as the message content of education, is ofcourse, have to be contextualized, adapted and relevant to the societal needs reflecting to the concrete and real condition of the stakholders. For preventing any kinds of terrorism, for long time frame, the curricullum of the education system - especially in any countries experincing those violent phenomena- have to bridge the needs for the people security and

structurally wants the harmonious, balanced, functional, and systemic life order. (see : Will Kymlicka, "Multicultural Citizenship", dalam Steven Seidmen and Jeffery C. Alexander (Ed.), The New Social Theory Reader, Rotledge, London, 2001, p.217.

${ }^{14}$ Religious inclusivism is any religious teachings or doctrines of certain religion contains any universal values or norms which tend to stress the similarity not difference of religion doctrine.. 
safety. In this case, for fulfilling those needs, so any structural conditions are necessary to develop. The government, in cooperation with all societal components, needs developing any kind of curricullua which are capable of creating the public or social awareness for preventing violent activities or actions including what is termed by terrorism. May be, subtantively, some subject-matters-such as multicultural education, human rights socialization, and recognition of religious diversification, will be more relevant to be taught in schools or society through the various didactical approaches \& methods. On the contrary, any subject-matters teaching "exclusive and extreme message"-whether culturally, politically, or religiously-based, it should be eliminated or reduced in order to make more effective in teaching subject-matters oriented to building peace and security of the society.

\section{Implication toward the Educational Environment}

An environment is any structural condition rounds a certain organization, process or anything else. In educational process, envi- ronment plays an important role in reaching the effectiveness of education. Consequently, any environment of education, must be structured condusively in a reach of the objective of education being processed.

In supporting the counter-terrorism education, any conducive environment can be designed and engineered by strengthening any form of student paricipation to prevent and eliminate any various form of social conflicts, violence, other deviative behavior-both in school campus or outside (in society). Conversely, the school or university must develop any type of norms, values, or doctrines teaching and respecting the pluralism, multi-culturalism, the differences. By means of creating the condusive, dialogal, and communicative enviromental culture, the programs of preventing terror acts can be structurally reduced and eliminated.

\section{Epilogue}

As the closing-sentence, in this subchapter, it would be wisely to draw some conclusions dealing with such above explanation and analysis. First, that terrorism whatever their types, motives and modus oper- 
andi should be regarded as the violent behaviour that can harms any other people at whole. In this case, ofcourse, all parties-the government, private actors, or all members of be improved to reach the objective of national development of Indonesia that is "the welfare, justice, and harmonious life for all the people".

\section{Referrences}

Anthony Smith, Theories of Nationalism, $2^{\text {nd }}$ Edt., Duckworth, London, 1983

Avyanthi Aziz, "Evolusi terorisme : Meninjau Teror dan Kekerasan dalam Konteks Historis", in the Jurnal Intelijen dan Kontra-Intelijen, Vol.1 no.6, Jakarta, Centre for the Study of Intelligence and Counter Intelligence.

Bruce Mazlish, "Religiosity a Last-Gasp Attack On Increasingly Secular World", Jakarta Post, 30 November, 2006

David Jary and Julia Jary, Unwin Hyman Dictionary of Sociology, Harper Collins Publishers, Leiicester, 1991

Hassan Wirajuda, "Challenging stereotyping of Islam, IVest", The Jakarta Post, November 29, 2006

bttp: / /www.odccp.org/odcop/terrorismdefinitions.htm! http://w.w.w.aseansec.org

http://www.apecsec.org.sg

Jeff Penrose, The DistillaryProject Director "The Criminology of Terrorism : History, Law, Definitions and Typologies": Course Readings for Senior Officer. The Distilary in cooperation with Faculty of Law, Wollongong University, and Center for Counter Terrorrism Study and Research, Singapore

Muqtedar Khan, "Radical Islam and 'Liberal Islam" in Current History, Vol 102, No.668, Dec.2003

Paul Eedle, The Language of Jibad, St. Andrew University, Scotland, 8 June 2002

Prent c.m, K., J.Adisubrata, and 'WJ.S Poerwadarminta, Kamus Latin-Indonesia, Penerbit Kanisius, Semarang, 1969

United Nations, A More Secure World : Our Shared Responsibiltiy, Report of the Secretary-General's HighLevel Panel on Threats, Challenges, and Change, New York, 2004.

UNTS 38349, The International Convention for the Suppression of the Financing of Terrorism, December, 1999, 2178.

Will Kymlicka, "Multicultural Citizenship", dalam Steven Seidmen and Jeffery C. Alexander (Ed.), The New Social Theory Reader, Rotledge, London, 2001. 